International Research Journal of Management, IT \& Social Sciences
Available online at https://sloap.org/journals/index.php/irjmis/
Vol. 6 No. 6, November 2019, pages: 111 117
ISSN: 2395-7492
https://doi.org/10.21744/irjmis.v6n6.773

\title{
Effect of Taxation Knowledge, Fiscus Service, and Tax Sanctions on Tax Obligation Compliance with Tax Amnesty as Moderated Variables
}

Kadek Pramesti Septyana ${ }^{a}$ Herkulanus Bambang Suprasto ${ }^{b}$ I.G.A.M Asri Dwija Putri ${ }^{c}$ Maria M. Ratna Sari ${ }^{d}$

Article history:

Received: 09 June 2019

Accepted: 30 September 2019

Published: 28 October 2019

\section{Keywords:}

fiscus service;

tax amnesty;

tax sanctions;

taxpayer compliance;

taxpayer knowledge;

\begin{abstract}
The purpose of this study was to determine the effect of tax knowledge, fiscus service, and tax sanctions on taxpayer compliance with tax amnesty as a moderating variable. This research was conducted at the North Badung Pratama Tax Service Office. The population is 65,550 taxpayers. The sample in this study used Convenience Sampling with the Slovin formula approach so that the number of studies numbered 100 people. The data analysis technique used is the MRA (Moderated Regression Analysis) analysis. The results showed that the knowledge of taxpayers had a positive and significant effect on taxpayer compliance. The fiscus service has a positive and significant impact on tax compliance. Sanctions have a positive and significant effect on taxpayer compliance. Tax amnesty reinforces the influence of taxpayer knowledge on taxpayer compliance. Tax amnesty strengthens the influence of the fiscus service on taxpayer compliance. Tax amnesty reinforces the effect of tax sanctions on tax compliance.
\end{abstract}

2395-7492@ Copyright 2019. The Author. This is an open-access article under the CC BY-SA license (https://creativecommons.org/licenses/by-sa/4.0/) All rights reserved.

\section{Author correspondence:}

Kadek Pramesti Septyana,

Udayana University, Denpasar, Indonesia.

Email address: pramesti_septyana@ymail.com

\section{Introduction}

Knowledge of taxation provides an important role for taxpayers to better understand the applicable tax regulations so that taxpayers can carry out their obligations properly and correctly. Compliance of taxpayers will increase along with the tax knowledge they have. Because with the high tax knowledge possessed, taxpayers will know the obligations and

${ }^{a}$ Udayana University, Denpasar, Indonesia

${ }^{\mathrm{b}}$ Udayana University, Denpasar, Indonesia

${ }^{c}$ Udayana University, Denpasar, Indonesia

${ }^{\mathrm{d}}$ Udayana University, Denpasar, Indonesia 
sanctions that will be obtained if they do not carry out their obligations (Sari \& Fidiana, 2017). This study is in line with research conducted by Rosyda (2018) and the results show that tax knowledge has a significant effect on taxpayer compliance. Inversely related to research conducted by Hardiningsih \& Yulianawati (2011), which states that understanding tax knowledge has no effect on the willingness to pay taxes. Lack of understanding of tax knowledge is due to the low education of taxpayers, which causes a lack of knowledge about tax regulations. Therefore, the role of the fiscus service is needed to increase understanding of taxation knowledge, training and outreach will increase understanding of existing taxation knowledge.

Good fiscal services will increase taxpayer's tax knowledge so that it will encourage taxpayers to be more obedient to their obligations to pay taxes. The tax apparatus has the responsibility to provide good services to the public. A fiscus service must have the competence to improve taxpayer compliance. Competencies that must be owned by the fiscus service, such as having expertise, knowledge (knowledge), and experience in terms of tax policy, tax administration and tax legislation (Jatmiko, 2006). Research conducted by Jatmiko (2006), states that fiscus service affects tax compliance.

Good fiscal services can be realized by providing socialization in the ease of tax reporting. In the Regulation of the Directorate General of Tax PER-03 / PJ / 2015, taxpayers can submit tax returns through electronic or online tax reporting channels that have been determined by the DGT (e-Filling). E-Filling provides benefits for taxpayers by facilitating the recording of SPT data in the DGT database and reducing the impact of the queue and volume of work for the SPT receipt process (www.online-pajak.com). Socialization can be done through workshops, seminars, print media, and electronic media. Through this socialization, it is expected to be able to raise awareness of taxpayers.

Quality services must be able to provide security, fluency, and can provide legal certainty that can be accounted for so as to reduce tax leaks (Hardiningsih \& Yulianawati, 2011). Providing quality services will increase tax compliance (Syahril, 2013). This research is also supported by research conducted by Dewi and Noviari (2017), the better the fiscus service, the higher the willingness to take part in tax amnesty. Inversely related to the research conducted by Sari \& Fidiana (2017); Ashari et al., (2017); Lisa \& Hermanto (2018), which states that the fiscus service does not affect tax compliance. The lack of influence is caused by the lack of responsibility of the fiscus service on taxpayers so that taxpayers do not have a bad assumption on the performance of the fiscus service.

Tax sanctions are set by the government to create taxpayer compliance with tax regulations. In general, people have a tendency to avoid taxes even though they know how the sanctions are. Tax sanctions are a deterrent so that taxpayers do not violate taxation norms. The effect of tax sanctions is caused by the large number of taxpayers who know and understand what sanctions will be imposed if taxpayers violate taxation provisions (Ashari et al., 2017). This is also in line with research by Ngadiman \& Huslin (2015), which states that tax sanctions have a positive effect to taxpayer compliance The positive effect shown by tax sanctions indicates that if taxpayer awareness increases, tax compliance rates will increase as well, and vice versa, as well as research conducted by Widodo (2017), with the results showing that sanctions tax has a significant effect on the compliance of individual taxpayers. This study is also supported by previous studies, namely Husnurrosyidah \& Nuraini (2016); Jatmiko (2006); Dewi \& Noviari (2017). Inversely with research conducted by Rorong et al., (2017), which states that Tax sanctions do not affect taxpayer compliance. Minor administrative and criminal tax sanctions cause non-compliance of taxpayers. This research was also supported by research conducted by Dewi \& Merkusiwati (2018).

\section{Literature Review and Hypothesis Development}

The results of research conducted by Sari \& Fidiana (2017), state that tax knowledge has a positive effect on taxpayer compliance. By having adequate tax knowledge, taxpayers can easily carry out their tax obligations. The higher level of understanding of taxpayers will increase taxpayer compliance. The results of this study are in line with research conducted by Syahril (2013); Rosyida (2018); Dewi \& Merkusiwati (2018); Prena et al., (2019). The level of tax knowledge is very important in determining the attitude of taxpayers. If knowledge of tax regulations is low, taxpayer compliance regarding taxation will also be low. Although the taxpayer does not intend to not carry out his obligations the taxpayer is still unable to meet his tax obligations because he himself does not understand tax regulations, this will result in a low level of tax compliance (Pandey, 2017; Lisa \& Hermanto, 2018).

Based on the description above, the first hypothesis in this study can be formulated as follows:

\section{H1: taxation knowledge has positive effect on taxpayer's compliance}

Research conducted by Hadiningsih \& Yulianawati (2011), states that service quality has a positive effect on taxpayer compliance. This research is also in line with research conducted by Jatmiko (2006); Hardiningsih \& Yulianawati 
(2011); Syahril (2013); Dewi \& Noviari (2017). Good service will help taxpayers to better understand their obligations. The better the services provided by the fiscus service will encourage taxpayers to carry out their obligations so that it will create taxpayer compliance. Conversely, if the services provided by the fiscus service are not good, taxpayers will be reluctant to fulfill their obligations, so that it will affect state revenue.

Based on the description above can be formulated the second hypothesis in this study are as follows:

H2: fiscus services have a positive effect on taxpayer compliance

The results of research conducted by Jatmiko (2006); Ngadiman \& Huslin (2015); Husnurrosyidah \& Nuraini (2016); Widodo (2017); Dewi \& Noviari (2017); Sari \& Wirakusuma (2018), state that tax sanctions have a positive effect on compulsory compliance tax. Tax sanctions are made so that taxpayers do not violate tax regulations. Understanding the fairly severe sanctions outlined in tax regulations will make taxpayers comply with their obligations. The heavier sanctions that apply, the taxpayer will be more compliance (Sentanu \& Budiartha, 2019; Seralurin \& Ermawati, 2019).

Based on the description above, the third hypothesis in this study can be formulated as follows:

H3: tax sanctions have a positive impact on personal taxpayer compliance

Tax amnesty is a government policy in the field of taxation that provides for the elimination of taxes that should be owed by paying a ransom in a certain amount that aims to provide additional state revenue and encourage compliance of non-compliant taxpayers into compliant taxpayers (Rahayu, 2017). Following the tax amnesty program will increase taxation knowledge about tax obligations and will create compliance for taxpayers. Therefore, this study uses the variable tax amnesty to moderate the relationship of the influence of tax knowledge on taxpayer compliance, so the fourth hypothesis in this study is as follows:

H4: tax amnesty strengthens the relationship between tax knowledge and taxpayer compliance Good fiscus service will make taxpayers voluntarily report their tax obligations. Tax amnesty increases the interest of the community to better understand the obligations that must be carried out in the taxation field. So that the tax amnesty will encourage taxpayers to disclose data correctly and completely. Taxpayers who receive education from the fiscus service on the importance of participating in the tax amnesty program will comply with tax regulations because they know the facilities and consequences if they join the tax amnesty program. Therefore, this study uses the tax amnesty variable to moderate the relationship between the fiscus service and tax compliance, so the fifth hypothesis in this study is as follows:

H5: Tax Amnesty strengthens the relationship between the fiscus service and taxpayer compliance

Tax sanctions are sanctions for taxpayers who do not meet their tax obligations in accordance with applicable tax regulations. Tax amnesty provides forgiveness for administrative sanctions and release from criminal sanctions. With strict sanctions will encourage taxpayers to carry out tax obligations with responsibility. Therefore, this study uses the variable tax amnesty to moderate the relationship of tax sanctions on taxpayer compliance, so the sixth hypothesis in this study is as follows:

H6: Tax Amnesty strengthens the relationship between tax sanctions and taxpayer compliance

\section{Materials and Methods}

This study uses primary data in the form of a questionnaire and the results of direct interviews with research subjects. Based on the hypothesis in the design of this study determined the variables used in research. There are 2 (two) variables, they are the independent variable and the dependent variable. The independent variables in this study are tax knowledge, fiscus service and tax sanctions while the dependent variable is taxpayer compliance. This study uses the tax amnesty variable as a moderating variable. The analysis technique used is the Multiple Regression analysis and Moderated Regression Analysis (MRA) to measure the moderating variables.

\section{Results and Discussions}

The results of the Moderated Regression Analysis are presented in Table 1.

Septyana, K. P., \& Suprasto, H. B. (2019). Effect of taxation knowledge, fiscus service, and tax sanctions on tax obligation compliance with tax amnesty as moderated variables. International Research Journal of Management, IT and Social Sciences, 6(6), 111-117. https://doi.org/10.21744/irjmis.v6n6.773 
Table 1

Moderated regression analysis

\begin{tabular}{|c|c|c|c|c|c|}
\hline Model & \multicolumn{2}{|c|}{$\begin{array}{c}\text { Unstandardized } \\
\text { Coefficient }\end{array}$} & $\begin{array}{l}\text { Standardized } \\
\text { Coefficient } \\
\text { Beta }\end{array}$ & $\mathrm{t}$ & Sig. \\
\hline (Constant) & 0.484 & 1.090 & & 0.444 & 0.658 \\
\hline $\mathrm{H} 4$ & 0.075 & 0.163 & 0.162 & 0.463 & 0.045 \\
\hline H5 & 0.667 & 0.132 & 0.207 & 0.044 & 0.000 \\
\hline H6 & 0.272 & 0.106 & 0.960 & 0.580 & 0.011 \\
\hline $\mathrm{R}$ Square $=0,819$ & & & & & \\
\hline$F$ hitung $=59,524$ & & & & & \\
\hline Sig. $F=0,000$ & & & & & \\
\hline
\end{tabular}

Primary Data, 2019

The Effect of Taxation Knowledge on Taxpayer Compliance

Taxpayer Knowledge (X1) has a positive regression coefficient of 0.226 with a significance level of 0,000 that is smaller than $\alpha=0.05$. These results indicate that there is a positive influence of taxpayer knowledge on taxpayer compliance, it shows that if taxpayer knowledge is increasing with the assumption that other independent variables are constant, then taxpayer compliance will increase. So that the proposed $\mathrm{H} 1$ can be accepted, it means that tax knowledge has a positive effect on tax compliance in obeying and fulfilling all tax obligations in North Badung KPP. The results of this study are in line with the results of research conducted by Sari \& Fidiana (2017), stating that tax knowledge has a positive effect on taxpayer compliance. By having adequate tax knowledge, taxpayers can easily carry out their tax obligations. The higher level of understanding of taxpayers will increase taxpayer compliance. The results of this study are in line with research conducted by Syahril (2013); Rosyida (2018); Dewi \& Merkusiwati (2018).

\section{The Effect of Fiscus Services on Taxpayer Compliance}

Fiscus Services (X2) has a positive regression coefficient of 0.334 with a significance level of 0,000 that is smaller than $\alpha=0.05$. These results indicate that there is a positive influence on the fiscus service on taxpayer compliance, it shows that if the fiscus service increase with the assumption that other independent variables are constant, then taxpayer compliance will increase. So $\mathrm{H} 2$ proposed can be accepted meaning that the fiscus service have a positive effect on tax compliance in obeying and fulfilling all tax obligations in North Badung KPP. The results of this study are supported by Hadiningsih \& Yulianawati (2011), stating that service quality has a positive effect on taxpayer compliance. This research is also in line with research conducted by Jatmiko (2006); Hardiningsih \& Yulianawati (2011); Syahril (2013); Dewi \& Noviari (2017). Good service will help taxpayers to better understand their obligations. The better the services provided by the fiscus service will encourage taxpayers to carry out their obligations so that it will create taxpayer compliance. Conversely, if the services provided by the fiscus service are not good, taxpayers will be reluctant to fulfill their obligations, so that it will affect state revenue.

\section{The Effect of Tax Sanctions on Taxpayer Compliance}

Tax Sanction (X3) has a positive regression coefficient of 0.181 with a significance level of 0,000 that is smaller than $\alpha=0.05$. This shows that if the tax sanction variable increases with the assumption that other independent variables are constant, the taxpayer compliance will increase. So that the proposed $\mathrm{H} 3$ can be accepted, it means that the tax sanction has a positive effect on the compliance of taxpayers in obeying and fulfilling all tax obligations in North Badung KPP. In line with research conducted by Jatmiko (2006); Ngadiman \& Huslin (2015); Husnurrosyidah \& Nuraini (2016); Widodo (2017); Dewi \& Noviari (2017); Sari \& Wirakusuma (2018), state that tax sanctions have a positive effect on compliance taxpayers. A tax deduction is made so that taxpayers do not violate tax regulations. Understanding the fairly severe sanctions outlined in tax regulations will make taxpayers comply with their obligations. The heavier sanctions that apply, the taxpayer will be more compliant.

Tax Amnesty Strengthens the Relationship Between Taxation Knowledge and Taxpayer Compliance

The moderation coefficient between taxpayer knowledge and tax amnesty is 0.075 which means that if there is an increase in the relationship of taxpayer knowledge with tax amnesty by one unit, then taxpayer compliance will increase by 0.075 units with the assumption that the independent variable is constant. This can be interpreted that tax 
amnesty reinforces the positive influence of taxpayer knowledge on taxpayer compliance. Tax amnesty is a government policy in the field of taxation that provides for the elimination of taxes that should be owed by paying a ransom in a certain amount that aims to provide additional state revenue and encourage compliance of non-compliant taxpayers into compliant taxpayers (Rahayu, 2017). Following the tax amnesty program will increase taxation knowledge about tax obligations and will create compliance for taxpayers. Therefore, this study uses the variable tax amnesty to moderate the relationship of the influence of tax knowledge on taxpayer compliance.

\section{Tax Amnesty Strengthens the Relationship between Fiscus Services and Taxpayer Compliance}

The moderation coefficient between the fiscus service and tax amnesty is 0.667 which means that if there is an increase in the relationship between the fiscus service and the tax amnesty by one unit, the taxpayer compliance will increase by 0.667 units with the assumption that the independent variable is constant. This can be interpreted that the tax amnesty strengthens the positive influence of the fiscus service on tax compliance. Good fiscus service will make taxpayers voluntarily report their tax obligations. Tax amnesty increases the interest of the community to better understand the obligations that must be carried out in the taxation field. So that the tax amnesty will encourage taxpayers to disclose data correctly and completely. Taxpayers who receive education from the fiscus service on the importance of participating in the tax amnesty program will comply with tax regulations because they know the facilities and consequences if they join the tax amnesty program. Therefore, this study uses the variable tax amnesty to moderate the relationship between the fiscus service and tax compliance.

\section{Tax Amnesty Strengthens the Relationship between Tax Sanctions and Taxpayer Compliance}

The moderation coefficient between tax sanctions and tax amnesty is 0.272 which means that if there is an increase in the relationship of tax sanctions with tax amnesty by one unit, the taxpayer compliance will increase by 0.272 units with the assumption that the independent variable is constant. This can be interpreted that tax amnesty reinforces the positive effect of tax sanctions on taxpayer compliance. Tax sanctions are sanctions for taxpayers who do not meet their tax obligations in accordance with applicable tax regulations. Tax amnesty provides forgiveness for administrative sanctions and release from criminal sanctions. With strict sanctions will encourage taxpayers to carry out tax obligations with responsibility. Therefore, this study uses the variable tax amnesty to moderate the relationship of tax sanctions on tax compliance.

\section{Determination Coefficient Test Results}

Based on Table 1, the Adjusted R-square value of 0.819 shows that taxpayer compliance can be explained by taxpayer knowledge, tax fiction, tax sanctions and tax amnesty of $81.9 \%$ percent, the remaining $18.1 \%$ percent is influenced by other variables not included in this research model.

\section{Conclusion}

Taxpayer compliance shows that taxpayers with high knowledge and understanding of taxation will be able to better determine their behavior and fulfill all tax obligations in accordance with applicable tax laws in Indonesia. The fiscus service has a positive and significant impact on tax compliance. Improving the fiscus service providing information related to tax rights and obligations will increase taxpayer compliance in fulfilling its obligations. Sanctions have a positive and significant effect on taxpayer compliance. Tax applies to taxpayers who violate the provisions of tax regulations will increase taxpayer compliance in fulfilling their obligations. Tax amnesty reinforces the influence of taxpayer knowledge on taxpayer compliance. Tax amnesty strengthens the influence of the fiscus service on taxpayer compliance. Tax amnesty reinforces the effect of tax sanctions on tax compliance.

\section{Suggestion}

It is hoped that the socialization policy on taxation will continue to provide knowledge of taxpayers. Socialization can be done directly (face to face) through seminars or indirectly such as advertisements and dissemination through print media. For further research should use other variables that are considered to have a more significant influence on taxpayer compliance, such as applicable tax regulations, tax calculation, and reporting or the taxpayer's financial condition.

Septyana, K. P., \& Suprasto, H. B. (2019). Effect of taxation knowledge, fiscus service, and tax sanctions on tax obligation compliance with tax amnesty as moderated variables. International Research Journal of Management, IT and Social Sciences, 6(6), 111-117. https://doi.org/10.21744/irjmis.v6n6.773 
Conflict of interest statement

The authors declared that they have no competing interests.

Statement of authorship

The authors have a responsibility for the conception and design of the study. The authors have approved the final article.

Acknowledgments

The authors would like to thank the editor of IRJMIS for their valuable time, support and advice in completing the current study. 


\section{References}

Ashari, A., Widodo, A. S., \& Utami, R. H. (2017). Pengaruh sunset policy, tax amnesty, sanksi pajak, e-spt dan kinerja account representative terhadap tingkat kepatuhan pajak. In Prosiding Seminar Nasional \& Internasional.

Dewi, N. P. A., \& Noviari, N. (2017). Pengaruh kesadaran wajib pajak, pelayanan fiskus, dan sanksi perpajakan pada kemauan mengikuti tax amnesty. E-Jurnal Akuntansi, 1378-1405.

Dewi, S. K., \& Merkusiwati, N. K. L. A. (2018). Pengaruh Kesadaran Wajib Pajak, Sanksi Perpajakan, E-Filing, dan Tax Amnesty Terhadap Kepatuhan Pelaporan Wajib Pajak. E-Jurnal Akuntansi, 1626-1655. https://doi.org/10.24843/EJA.2018.v22.i02.p30

Hardiningsih, P., \& Yulianawati, N. (2011). Faktor-faktor yang mempengaruhi kemauan membayar pajak. Dinamika Keuangan dan Perbankan, 3(1), 126-142.

Husnurrosyidah, H., \& Nuraini, U. Pengaruh tax amnesty dan sanksi pajak terhadap kepatuhan pajak, Equilibrium: Jurnal Ekonomi Syariah, 4(2).

Jatmiko, A. N. (2006). Pengaruh Sikap Wajib Pajak pada Pelaksanaan Sanksi Denda, Pelayanan Fiskus dan Kesadaran Perpajakan terhadap Kepatuhan Wajib Pajak (Studi Empiris terhadap Wajib Pajak Orang Pribadi di Kota Semarang) (Doctoral dissertation, Program Pasca Sarjana Universitas Diponegoro).

Lisa, O., \& Hermanto, B. (2018). The effect of tax amnesty and taxpayer awareness to taxpayer compliance with financial condition as intervening variable. International Research Journal of Management, IT and Social Sciences, 5(2), 227-236.

Ngadiman, N., \& Huslin, D. (2015). Pengaruh Sunset Policy, Tax Amnesty, Dan Sanksi Pajak Terhadap Kepatuhan Wajib Pajak (Studi Empiris di Kantor Pelayanan Pajak Pratama Jakarta Kembangan). Universitas Tarumanagara Journal of Accounting, 19(2).

Pandey, M. (2017). Impact of goods and service tax (GST) on Indian tax structure. International Research Journal of Management, IT and Social Sciences, 4(3), 22-33.

Prena, G. D., Kustina, K. T., Dewi, I. G. A. A. O., Putra, I. G. C., \& Krisnanda, R. A. (2019). Tax sanctions, tax amnesty program, and tax obligation placement towards compliance report on corporate taxpayers. International Journal of Social Sciences and Humanities, 3(1), 26-35. https://doi.org/10.29332/ijssh.v3n1.249

Rahayu, S. K. (2017). Perpajakan-Konsep dan Aspek Formal. Bandung: Rekayasa Sains.

Rorong, E. N., Kalangi, L., \& Runtu, T. (2017). Pengaruh Kebijakan Tax Amnesty, Kesadaran Wajib Pajak dan Sanksi Pajak Terhadap Kepatuhan Wajib Pajak Orang Pribadi di KPP Pratama Manado. Jurnal Riset Akuntansi Going Concern, 12(2). https://doi.org/10.32400/gc.12.2.17480.2017

Rosyida, I., Peng, J., Chen, L., Widodo, W., Indrati, C. R., \& Sugeng, K. A. (2018). An uncertain chromatic number of an uncertain graph based on \$\$lalpha \$\$-cut coloring. Fuzzy Optimization and Decision Making, 17(1), 103123. https://doi.org/10.1007/s10700-016-9260-X

Sari, K. G. A., Wirakusuma, M. G., \& Ratnadi, N. M. D. (2018). Pengaruh Skeptisisme Profesional, Etika, Tipe Kepribadian, Kompensasi, Dan Pengalaman Pada Pendeteksian Kecuarngan. E-Jurnal Ekonomi dan Bisnis Universitas Udayana, 29-56. https://doi.org/10.24843/EEB.2018.v07.i01.p02

Sari, V. A. P. Fidiana.(2017). Pengaruh Tax Amnesty, Pengetahuan Perpajakan, dan Pelayanan Fiskus Terhadap Kepatuhan Wajib Pajak. Jurnal Ilmu Dan Riset Akuntansi, 6(2), 744-760.

Sentanu, I. N. W., \& Budiartha, K. (2019). Effect of taxation modernization on tax compliance. International Research Journal of Management, IT and Social Sciences, 6(4), 207-213. https://doi.org/10.21744/irjmis.v6n4.683

Seralurin, Y. C., \& Ermawati, Y. (2019). Influence of self-assessment system, taxation understanding, and discrimination toward ethics of tax evasion. International Research Journal of Management, IT and Social Sciences, 6(5), 267-278. https://doi.org/10.21744/irjmis.v6n5.745

Syahril, F. (2013). Pengaruh tingkat pemahaman wajib pajak dan kualitas pelayanan fiskus terhadap tingkat kepatuhan wajib pajak PPh orang pribadi (studi empiris pada KPP Pratama Kota Solok). Jurnal Akuntansi, 1(2).

Widodo, T. (2017). The Impact of Deficit or Surplus Firm, Corporate Income Tax on the Speed of Adjustment Toward to Target Leverage.

Septyana, K. P., \& Suprasto, H. B. (2019). Effect of taxation knowledge, fiscus service, and tax sanctions on tax obligation compliance with tax amnesty as moderated variables. International Research Journal of Management, IT and Social Sciences, 6(6), 111-117. https://doi.org/10.21744/irjmis.v6n6.773 